\title{
Growth of three types of sengon (Paraserianthes spp.) in varying planting spaces in agroforestry system
}

\author{
FRISILIA SOPACUA ${ }^{1, \vartheta}$, NURHENI WIJAYANTO ${ }^{2, v \vartheta}$, DESTA WIRNAS ${ }^{3}$ \\ ${ }^{1}$ Program of Tropical Silviculture, School of Graduates, Institut Pertanian Bogor. Jl. Lingkar Kampus IPB Darmaga, Bogor 16680, West Java, Indonesia. \\ Tel./fax. +62-251-8622642, `email: frisilia.sopacua@gmail.com. \\ ${ }^{2}$ Department of Silviculture, Faculty of Forestry, Institut Pertanian Bogor. J1. Ulin, Kampus IPB Darmaga, Bogor 16680, West Java, Indonesia. \\ Tel.: +62-251-8621677, Fax.: +62-251-8621256, “wemail: nurheniw@gmail.com \\ ${ }^{3}$ Department of Agronomy and Horticulture, Faculty of Agriculture, Institut Pertanian Bogor. Jl. Meranti, Kampus IPB Darmaga, Bogor 16680, West \\ Java, Indonesia. Tel.: +62-251-8629354, Fax.: +62-251-8629352
}

Manuscript received: 25 May 2021. Revision accepted: 25 September 2021.

\begin{abstract}
Sopacua F, Wijayanto N, Wirnas D. 2021. Growth of three types of sengon (Paraserianthes spp.) in varying planting spaces in agroforestry system. Biodiversitas 22: 4423-4430. Sengon (Paraserianthes spp.) is a fast-growing tree species that is commonly cultivated in the agroforestry system by communities in Indonesia, mainly on Java Island. Among several types of sengon, Solomon sengon is currently gaining popularity due to the fast growth in height and stem diameter. Nonetheless, the spacing layout of selected sengon types is unclear, including Solomon sengon, which yields more optimal growth. This study aimed to examine the growth of three sengon types (i.e., Solomon F2, Solomon F1, and local Kendal) in three spacing patterns, namely $1.5 \times 1.5 \mathrm{~m}, 3 \times 1.5 \mathrm{~m}$, and $3 \times 3 \mathrm{~m}$. This research was conducted from October 2019 to January 2020 (three months) in the Cikabayan Forest, Bogor Agricultural University, Bogor, West Java. The parameters of sengon growth observed were plant height, height growth rate, stem diameter, stem diameter growth rate, tree volume, and canopy area. Data analysis was performed using ANOVA and continued with Duncan's. The results showed that all types of sengon had optimal growth in the agroforestry system at various spacings. The growth of Solomon F2 adapted well to denser spacings $(1.5 \times 1.5 \mathrm{~m}$ and $1.5 \times 3 \mathrm{~m})$ with the highest averages in plant height, stem diameter, volume, and canopy area of $10.50 \mathrm{~m}, 8.65 \mathrm{~cm}, 0.36 \mathrm{~m}^{3}$, and $5.39 \mathrm{~m}^{2}$. Local Kendal had optimal growth at a wider spacing $(3 \times 3 \mathrm{~m})$ with the highest average stem diameter, volume, and canopy area of $8.96 \mathrm{~cm}, 0.043 \mathrm{~m}^{3}$, and $1063 \mathrm{~m}^{2}$. While Solomon F1 adapted well to the three spacings with the highest average in plant height, the growth rate of plant height, stem diameter, volume, and canopy area of $10.05 \mathrm{~m}, 1.54 \mathrm{~m}, 8.59 \mathrm{~cm}$, $0.042 \mathrm{~m}^{2}$, and $2075.30 \mathrm{~m}^{2}$. In general, it can be concluded that the Solomon F1 sengon can adapt well to narrow distances or wide distances. While Solomon F2 is more recommended to be planted at a narrower distance and Kendal local sengon is more recommended to be planted at a wider distance to get optimal growth.
\end{abstract}

Keywords: Agroforestry, fertilization, sengon Solomon, stem diameter

\section{INTRODUCTION}

Agroforestry (AF) is a land-use management system that combines agriculture and forest practices by planting agricultural crops along with forestry trees to be managed as a sustainable system (Sarminah et al. 2018; Agu et al. 2019). From an agroecological perspective, agroforestry forms multi-strata canopy layers that are beneficial for soil conservation. It can reduce the speed of rainwater, minimizing the potential risk of erosion caused by run-off water (Sepulveda and Carrillo et al. 2015; Sollen-Norrlin et al 2020). With the soil structure maintained from run-off water, agroforestry can increase the soil nutrient availability due to the litterfall from the trees (Dollinger and Jose 2018). The soil in the agroforestry system has more advantages than that in monoculture crops since it has more microbial diversity (Udawatta 2019), which can improve soil fertility (Khalif et al. 2014; Iskandar et al. 2017). Along with the increased organic carbon content, the soil $\mathrm{C} / \mathrm{N}$ ratio and organic materials in the agroforestry land can promote plant growth (Utomo et al. 2016). The intercropping system in agroforestry can also reduce the spread of pests and diseases (Lestari et al. 2013; Rahayu et al. 2021) compared to the monoculture system (Darwiati and Anggraeni 2018; Nugroho et al. 2021). From a socioeconomic view, the agroforestry system is a win-win option that can become an income source for the community (Premono and Lestari 2018; Pachas et al. 2019) without changing the field tradition (huma) (Iskandar et al. 2017).

In managing an agroforestry system, the selection of plant species is the key consideration to achieve sustainability (Japarudin et al. 2020). When doing so, it should take into account several aspects, including climate condition, topographical factor, growth requirements, and local community socio-economic conditions (Agu et al. 2019; Nuroniah et al. 2021). One tree species that is gaining popularity to be cultivated in agroforestry is sengon (Paraserianthes spp.). Sengon is fast-growing tree species and very easy to adapt to various soil conditions (Krisnawati et al. 2011; Wasis and Saidah 2019). In Indonesia, Sengon has been planted either on a small scale by individual farmers or by companies on a large commercial scale. This plant has high economic value to be developed as raw materials for pulp, paper, and plywood industries (Krisnawati et al. 2011; Darmawan et al. 2015). 
In the agroforestry system, sengon is an ideal tree plant because it has an open crown. The light can go through into the ground, and the lower canopy space can be cultivated with agricultural crops (Wijayanto and Pratiwi 2011). The commonly used undergrowth crops in the agroforestry system are food-producing plants, for example, rice. Rice has a high economic value for the community, either selfconsumed or as cash income (Nurliza et al. 2017; Kadigi et al. 2020). Several types of sengon trees have been planted in Indonesia, including two types of origins, namely local sengon and Solomon sengon. Local sengon types are originated from Indonesia regions and have been developed by local communities for decades. Several types of local sengon include Kendal, Temanggung, and Wonosobo. Solomon sengon is a sengon that originated from Solomon Islands in Pacific Ocean and is now gaining attention since in general, Solomon sengon has a faster growth than the local sengon types (Setiadi et al. 2014; Azizah et al. 2019).

The pattern of planting sengon in the agroforestry system can affect the growth of sengon and the undergrowth crops, especially as the age of sengon increases (Azizah et al. 2019). Spacing can also affect canopy characteristics and wood quality (Tun et al. 2018). Spacing needs to be adjusted so that the undergrowth seasonal crops or agricultural crops can grow optimally (Wijayanto and Nurunnajah 2012). For example, Senjaya et al. (2018) found that in agroforestry land, upland rice planted under a three-month-old sengon stand with a spacing of $1.5 \times 1.5 \mathrm{~m}$ did not affect upland rice production or growth of sengon. In contrast, upland rice planted under a 2-year-old sengon stands with a spacing of $2.5 \times 2.5 \mathrm{~m}$ reduced upland rice production due to lack of received sunlight (Senjaya et al. 2018). In another study, a threeyear-old sengon stand at $3 \times 3 \mathrm{~m}$ spacing can increase the growth of height, stem diameter, and root length of sengon compared to monoculture system (Ningrum et al. 2019).
Studies on the growth of sengon planted in agroforestry and monoculture systems have long been performed. However, information of the growth of particular types of the Solomon F2, Solomon F1, and local Kendal in the agroforestry system is still limited. Previously, Azizah et al. (2019) investigated the growth of three sengon types (i.e., Solomon F2, Solomon F1, and local Kendal) and rice plant at 3-6 months after planting. The results showed that the Solomon F1 sengon obtained the highest tree height, stem diameter, canopy area, and root length compared to Solomon F2 and local Kendal types.

Yet, it was not clear from such a previous study regarding the planting space that produces the best growth. Therefore, this study aimed to examine the growth of three sengon types (i.e., Solomon F2, Solomon F1, and local Kendal) in varying spacing patterns. From this study, it can be inferred that the optimal sengon type and spacing can be suggested to be selected and planted in the agroforestry system.

\section{MATERIALS AND METHODS}

\section{Study area and period}

This study was performed in Cikabayan Forest, Darmaga Campus, Bogor Agricultural University, Bogor, West Java, Indonesia. The experimental site is located at the coordinates $06^{\circ} 32^{\prime} 48.8^{\prime \prime} \mathrm{S} 06^{\circ} 43^{\prime} 02.4^{\prime \prime} \mathrm{E}$ (Figure 1). This experiment was carried out from October 2019 to January 2020, starting at the beginning of the rainy season, to provide the plants with sufficient water. The rainfall during the four months of observation was 381.9, 330.1, 552.8, and $383.5 \mathrm{~mm} / \mathrm{month}$, respectively (BMKG 2020). The humidity and temperature at the study location were $70-73 \%$ and $29.8-30.73{ }^{\circ} \mathrm{C}$.

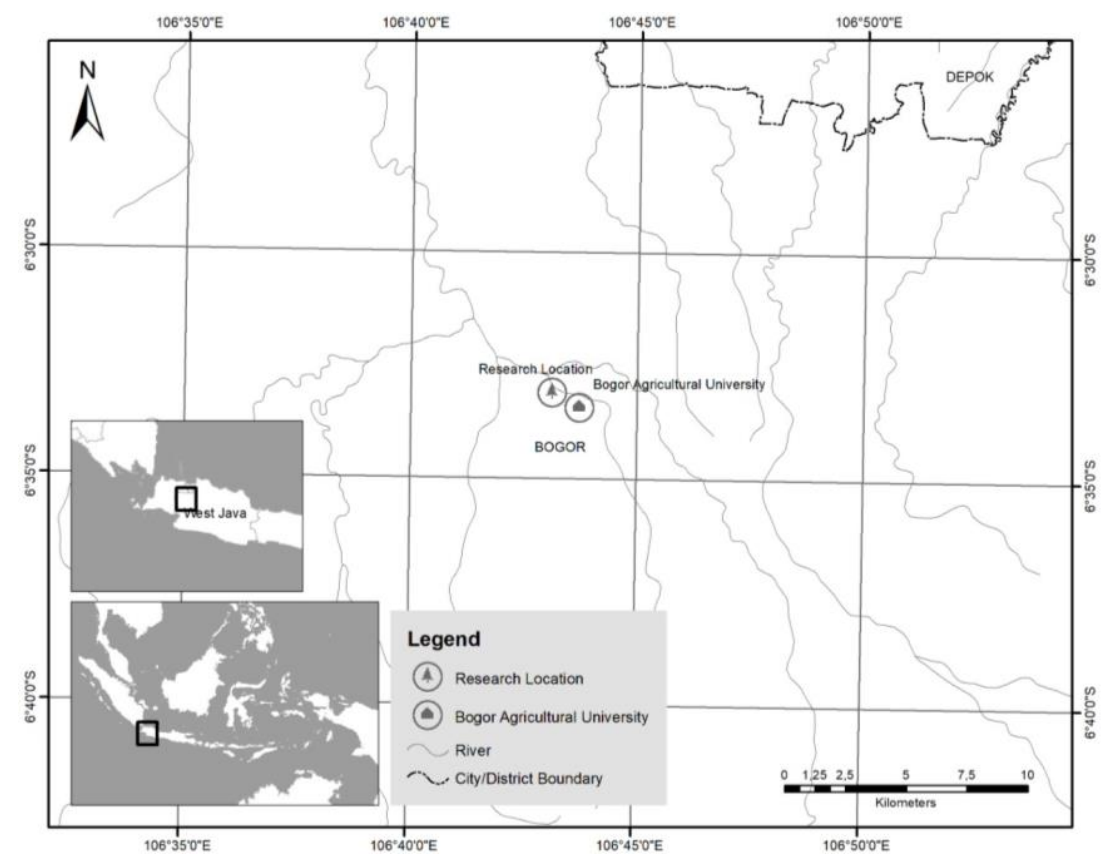

Figure 1. Map of the experimental site in Cikabayan Forest, Bogor Agricultural University, Bogor, West Java, Indonesia 


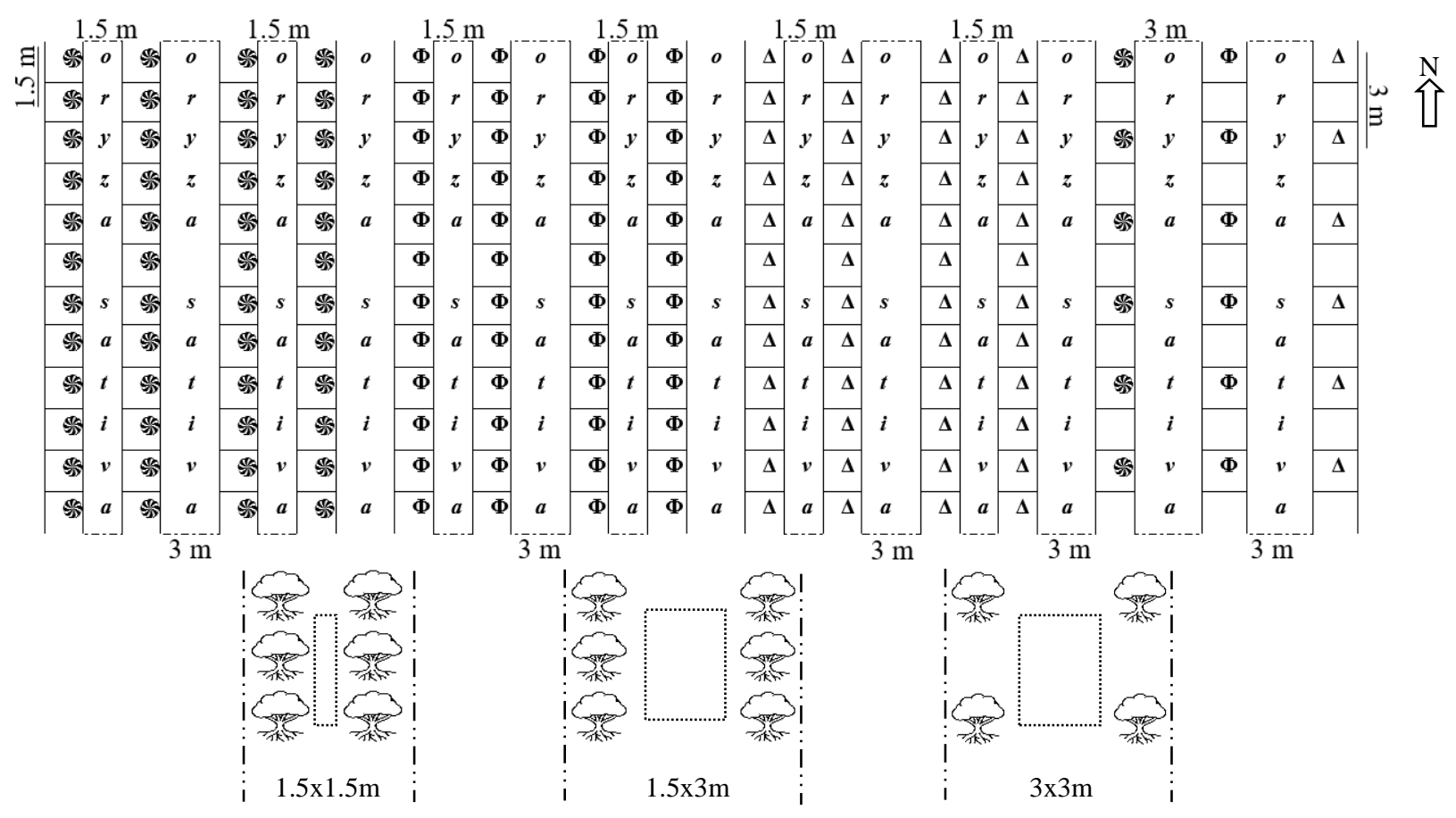

Figure 2. Research layout of agroforestry system of sengon intercropped with rice (Oryza sativa) using two factors: i.e., sengon ( $\$ 5$ : Solomon F2, $\Phi$ : Solomon F1, $\Delta$ : Local Kendal $)$, and planting space $(1.5 \times 1.5 \mathrm{~m}, 3 \times 1.5 \mathrm{~m}$, and $3 \times 3 \mathrm{~m})$

Table 1. Soil chemical properties at two cultivation period

\begin{tabular}{lll}
\hline Variable & Before rice planting & After rice harvesting \\
\hline pH H20 & 5.77 (slightly acid) & 6.06 (slightly acid) \\
C-organic (\%) & 2.60 (medium) & 2.94 (medium) \\
KTK & 17.53 (medium) & 17.02 (medium) \\
P-available & 7.01 (low) & 20.73 (very high) \\
N-total (\%) & 0.20 (low) & 0.24 (medium) \\
C/N Ratio & 13 (medium) & 12 (medium) \\
Base saturation & 31.66 (low) & 69.15 (high) \\
\hline
\end{tabular}

Note: The data presented were based on the soil chemical analysis in ICBB (Indonesian Center for Biodiversity and Biotechnology); The assessment criteria referred to Balitbangtan (2005).

The soil at the research site is red-yellow podzolic (Azizah et al. 2019), with properties are presented in Table 1. The soil $\mathrm{pH}$ before and after planting was 5.77-6.06, which were categorized as fairly acid (Balitbangtan 2005). Before rice plant planting, the soil had low total-N, moderate organic- $\mathrm{C}$, low available- $\mathrm{P}$, moderate $\mathrm{C} / \mathrm{N}$ ratio, moderate CEC, and low basic saturation. After three months, some soil properties increased, including moderate total-N, high basic saturation, and very high available-P.

\section{Plant materials and site preparation}

Three sengon types were used in this study, namely local Kendal, which is local sengon type obtained from Kendal; Solomon F1, which is Solomon type obtained from cultivated plants in Kendal Regency, Central Java; and Solomon F2, which is Solomon type crossed with local Kendal type. The age of the plants when this experiment was started was 14 months after planting (MAP).

The soil at the experiment site was prepared using common techniques, such as clearing weeds and tilling the soil by hoe to make the soil becomes loose. A plot was made between the stands of sengon to plant rice, with the distance between the sengon and the upland rice was 50 $\mathrm{cm}$. Dolomite with a dose of $600 \mathrm{~kg} / 1500 \mathrm{~m}^{2}$ was given two weeks before basic fertilization. Soil acidity was reduced by liming or by fertilizing phosphate and KCL (Sudaryono, 2009). Urea, SP-36, and KCL were applied at ten days after planting (DAP) to upland rice with a dose of $15 \mathrm{~kg} / 1500$ $\mathrm{m}^{2}$ for each type of fertilizer. Then the fertilization was carried out again at 20 DAP with $15 \mathrm{~kg} / 1500 \mathrm{~m}^{2}$ of urea. The fertilization was done by making an array next to the rice about $1-2 \mathrm{~cm}$ according to the prescribed dose.

\section{Experimental procedure}

The experiment was designed as a factorial, completely randomized design with two factors. The first factor was the sengon types, namely Solomon F2, Solomon F1, and local Kendal, while the second factor was the spaces, namely $1.5 \times 1.5 \mathrm{~m} .3 \times 1.5 \mathrm{~m}$ and $3 \times 3 \mathrm{~m}$. The layout of sengon and rice planting can be seen in Figure 2. The light intensity at each spacing was 1383.6 lux $(1.5 \times 1.5 \mathrm{~m}), 1623.3$ lux $(1.5 \times 3 \mathrm{~m})$, and 2259.6 lux $(3 \times 3 \mathrm{~m})$. Each treatment used eight replications with a sample of 72 plants.

\section{Sengon growth parameters observed Plant height}

The measurement of sengon height used a pole or a hypsometer. This measurement was carried out once a month until the rice harvest. 


\section{Plant height growth rate}

The plant height growth rate was calculated based on the difference in height between the beginning of the observation and the end of the observation.

\section{Stem diameter}

The stem diameter of sengon was measured at breast height (dbh) which is about $1.30 \mathrm{~m}$ from the base of the stem. The measurement used a tape measure and was carried out once a month until the rice was harvested.

$$
\begin{aligned}
& \mathrm{d}=\mathrm{K} / \pi \\
& \text { Where: } \\
& \mathrm{d}: \text { Diameter }(\mathrm{cm}) \\
& \mathrm{K}: \text { Circumference } \\
& \pi \quad \text { : Constant }(3.14)
\end{aligned}
$$

\section{The growth rate of stem diameter}

The rate of growth of stem diameter was calculated based on the difference in diameter between the beginning of the observation and the end of the observation.

\section{Tree volume}

Tree volume uses a combination of tree height and trunk diameter, but according to Ardelina et al. (2015) stated that the determination of the volume of the sengon tree can be calculated based on the diameter of the trunk using the formula.

Tree volume can be estimated using a combination of tree height and trunk diameter, but according to Ardelina et al. (2015), the volume of the sengon tree can be calculated using trunk diameter only as follow:

$\mathrm{V}=0.000213 \mathrm{D}^{2.37}$

\section{Canopy area}

The canopy/crown area was measured as the length and width of the canopy using a meter and was done month until the rice was harvested.

$$
\begin{aligned}
& \mathrm{x}=\mathrm{a}+\mathrm{b} ; \mathrm{y}=\mathrm{c}+\mathrm{d} ; \mathrm{r}=\frac{x+y}{2} \\
& \mathrm{LT}=\frac{1}{4} \times \pi \times \mathrm{rr}^{2}
\end{aligned}
$$

Where:

$$
\begin{array}{ll}
\text { CA } & \text { : Canopy area }\left(\mathrm{m}^{2}\right) \\
\text { LA } & : \text { Land area }(1 / 4) \\
\pi & : \text { Constant }(3.14) \\
\mathrm{r}^{2} & : \text { radius }(\mathrm{m}) \\
\mathrm{x} & : \text { canopy length } \\
\mathrm{y} & \text { : canopy width }
\end{array}
$$

\section{Data analysis}

The data were analyzed using analysis of variance (ANOVA). Further test using the Duncan test (Duncan Multiple Range Test) was conducted if the ANOVA had a significant effect at the 5\% level of confidence. Statistical analysis used SAS 9.4 Software.

\section{RESULTS AND DISCUSSION}

Trees with fast growth rates will yield high productivity, yet they require the most suitable plant type and spacing management. Accordingly, the selection of sengon to be cultivated in an agroforestry system intercropped with rice requires correct choice of sengon type and planting space, which might differ in every sengon type (Widiyanto et al. 2013). Based on the results of the analysis of variance (ANOVA), Table 2 shows that the type of sengon significantly affected the canopy area, while the spacing had a significant effect on plant height and canopy area. The interaction between sengon type and plant spacing significantly affected plant height, plant height growth rate, stem diameter, tree volume, and canopy area. However, it was not significantly different for the growth rate of stem diameter.

\section{Effects of sengon types and spacing on plant height and height growth rate}

The result of Duncan's to see the effect of sengon type and spacing on plant height and height growth rate at 16 months after planting is presented in Table 3. Spacing treatment had no significant effect on the height of Solomon F1 and local Kendal sengon types, while spacing treatment had a significant effect on the height of the Solomon F2 in which spacing at $3 \times 3 \mathrm{~m}$ yielded the lowest height. In addition, narrow spacing had a significant effect on the height growth rate of Solomon F1 which the spacing of $1.5 \times 1.5 \mathrm{~m}(1.54 \mathrm{~m})$ resulted in the highest growth rate across all treatments (Table 3 ).

Table 2. The results of ANOVA on the effect of sengon type and planting space on all growth parameters

\begin{tabular}{lcccc}
\hline \multirow{2}{*}{ Observational variables } & \multicolumn{3}{c}{ Treatment } & \multirow{2}{*}{ Coefficient of variance $(\%)$} \\
\cline { 2 - 3 } & Sengon type & Spacing & Interaction & 9.75 \\
Plant height & $\mathrm{ns}$ & $*$ & $*$ & 1.66 \\
Plant height growth rate & $\mathrm{ns}$ & $\mathrm{ns}$ & $*$ & 13.19 \\
Stem diameter & $\mathrm{ns}$ & $\mathrm{ns}$ & $\mathrm{ns}$ & 3.67 \\
Stem diameter growth rate & $\mathrm{ns}$ & $\mathrm{ns}$ & $*$ & 17.91 \\
Tree volume & $\mathrm{ns}$ & $\mathrm{ns}$ & $*$ & 3.82 \\
Canopy area & $*$ & $*$ & \\
\hline
\end{tabular}

Note: ns: treatments had no significantly difference at 5\% with $(\operatorname{Pr}>\mathrm{F}) 0.05(\alpha) ;{ }^{*}$ : treatments had significant difference at $5 \%$ with $(\operatorname{Pr}>$ F) $0.05(\alpha)$. 
The lower height of Solomon F2 at the spacing of 3x3m was thought to be due to the lower adaptability of Solomon F2 at a wider planting distance than narrower spacing. Susanto and Baskorowati (2018) reported that Solomon sengon has high adaptability to various environmental conditions, which is influenced by its genetic factor. According to Ikhfan and Wijayanto (2019), tree growth is strongly influenced by genetic variables and adaptability to the environment. Suitable environmental factors can provide more optimal growth to the plant types (Hayati et al. 2012). Nevertheless, Azizah et al. (2019) and Ikhfan and Wijayanto (2019) explained that Solomon sengon had faster growth than the local Kendal sengon type.

Similar result was also found by Wahyudi et al. (2014) and Schwerz et al. (2020) that narrow spacing resulted in higher plant height growth than wider spacing. This condition was thought due to competition in narrow spacing, as trees responded to environmental factors, such as temperature and light intensity, which increased the auxin hormone for cell elongation. According to Susanto and Baskorowati (2018), tree height (tree height and diameter) was dominantly caused by environmental variation. Environmental factors, such as temperature, humidity, and rainfall, can influence plant growth (Messaoud and Chen 2011).

\section{Effects of sengon types and spacing on stem diameter and stem diameter growth rate}

Tree planting in an agroforestry system requires a particular spacing to gain greater diameter (Wahyudi et al. 2014). A wider spacing reduces the density of the planted trees and lessens nutrient competition among the trees (Widiyanto et al. 2013).

A significant difference caused by sengon type and spacing interaction on stem diameter was only found in the Solomon F2 type, which occurred at a planting space of 3x3m (Table 3). In contrast, Solomon F1 and local Kendal have no significant difference in all spacing treatments.
The average stem diameter in local Kendal at $3 \times 3 \mathrm{~m}$ yielded the highest diameter $(8.96 \mathrm{~m})$ than in Solomon F1 $(7.52 \mathrm{~m})$ and Solomon F2 $(5.23 \mathrm{~m})$ at a similar planting space. This finding is in contrast with Azizah et al. (2019) that found Solomon sengon diameter yielded a greater diameter than the local Kendal sengon type. This difference was thought due to local Kendal adaptability to a wider spacing which showed a positive response to growth. According to Ozcelik et al. (2014), each tree type performs different height and diameter due to the genetic capability and its interaction with the surrounding environmental condition. In general, wider planting space will result in a greater stem diameter (Rahman et al. 2018; Tun et al. 2018) since there is more abundant sunlight received by plants that will help the photosynthesis process.

Maintenance and fertilization applied in rice plants had a positive response to sengon growth. Senjaya et al. (2018) stated that sengon height and diameter growth were more improved in the agroforestry system than in the monoculture pattern. This is because land management in agroforestry often involves soil treatments (such as tillage and fertilization) which can affect the soil quality (in terms of structure and nutrient supply), which is beneficial for sengon growth (Ikhfan and Wijayanto 2019; Senjaya et al. 2018). In addition, tree density will affect competition among plants in nutrient, water, and sunlight absorptions.

The growth rate of stem diameter showed no significant difference in all treatment interactions. Hartoyo et al. (2014) stated that the planting pattern of sengon did not significantly affect the increase in diameter of sengon if only three months observation. Krisnawati et al. (2011) also stated that the growth of sengon diameter fluctuated up to the age of 6 years. In addition, it is suspected that the growth of sengon at the age of 16 months after planting is still focused on the growth of plant height so that the results of photosynthesis are more widely used to increase the rate of growth of plant height.

Table 3. Growth responses in term of plant height, plant height growth rate, stem diameter, stem diameter growth rate, tree volume, and canopy area of three sengon types in three spacing treatments

\begin{tabular}{|c|c|c|c|c|c|c|c|}
\hline \multirow[b]{2}{*}{$\begin{array}{l}\text { Type } \\
\text { sengon }\end{array}$} & \multirow[b]{2}{*}{ Spacing } & \multicolumn{6}{|c|}{ Parameters } \\
\hline & & $\begin{array}{l}\text { Plant } \\
\text { height } \\
(\mathbf{m})\end{array}$ & $\begin{array}{l}\text { Plant height } \\
\text { growth rate } \\
(\mathrm{m})\end{array}$ & $\begin{array}{c}\text { Stem } \\
\text { diameter } \\
(\mathrm{cm})\end{array}$ & $\begin{array}{l}\text { Stem diameter } \\
\text { growth rate } \\
(\mathrm{cm})\end{array}$ & $\begin{array}{c}\text { Tree } \\
\text { volume } \\
\left(\mathbf{m}^{3}\right)\end{array}$ & $\begin{array}{c}\text { Canopy } \\
\text { area } \\
\left(\mathbf{m}^{2}\right)\end{array}$ \\
\hline \multicolumn{8}{|c|}{ Solomon F2 } \\
\hline & $1.5 \times 1.5 \mathrm{~m}$ & $10.01 \pm 1.17 \mathrm{ab}$ & $0.90 \pm 0.11 \mathrm{~b}$ & $8.03 \pm 1.11 \mathrm{a}$ & $1.74 \pm 1.05 \mathrm{a}$ & $0.031 \pm 0.009 \mathrm{abc}$ & $530.2 \pm 138.1 \mathrm{c}$ \\
\hline & $1.5 \times 3 \mathrm{~m}$ & $10.50 \pm 1.63 \mathrm{a}$ & $0.91 \pm 0.17 \mathrm{~b}$ & $8.65 \pm 1.89 \mathrm{a}$ & $2.24 \pm 1.45 \mathrm{a}$ & $0.036 \pm 0.018 \mathrm{ab}$ & $539.1 \pm 144.5 \mathrm{c}$ \\
\hline & $3 \times 3 m$ & $6.61 \pm 1.47 \mathrm{c}$ & $1.05 \pm 0.21 \mathrm{~b}$ & $5.23 \pm 1.59 \mathrm{~b}$ & $1.28 \pm 0.63 \mathrm{a}$ & $0.013 \pm 0.009 \mathrm{c}$ & $536.9 \pm 235.6 \mathrm{~cd}$ \\
\hline \multicolumn{8}{|c|}{ Solomon F1 } \\
\hline & $1.5 \times 1.5 \mathrm{~m}$ & $9.75 \pm 1.65 \mathrm{ab}$ & $1.54 \pm 1.15 \mathrm{a}$ & $7.80 \pm 1.79 \mathrm{a}$ & $1.15 \pm 0.81 \mathrm{a}$ & $0.030 \pm 0.018 \mathrm{abc}$ & $398.9 \pm 199.5 \mathrm{~d}$ \\
\hline & $1.5 \times 3 \mathrm{~m}$ & $10.05 \pm 3.08 \mathrm{ab}$ & $0.92 \pm 0.09 \mathrm{~b}$ & $8.59 \pm 3.17 \mathrm{a}$ & $1.55 \pm 1.44 \mathrm{a}$ & $0.042 \pm 0.033 \mathrm{ab}$ & $531.9 \pm 288.1 \mathrm{~cd}$ \\
\hline & $3 \times 3 \mathrm{~m}$ & $9.27 \pm 4.66 \mathrm{ab}$ & $0.88 \pm 0.11 \mathrm{~b}$ & $7.52 \pm 2.99 \mathrm{a}$ & $1.55 \pm 0.38 \mathrm{a}$ & $0.033 \pm 0.03 \mathrm{ab}$ & $2075.3 \pm 2071.6 \mathrm{a}$ \\
\hline \multicolumn{8}{|c|}{ Local Kendal } \\
\hline & $1.5 \times 1.5 \mathrm{~m}$ & $9.94 \pm 1.75 \mathrm{ab}$ & $0.95 \pm 0.25 \mathrm{~b}$ & $7.22 \pm 1.44 \mathrm{a}$ & $1.37 \pm 1.11 \mathrm{a}$ & $0.025 \pm 0.011 \mathrm{bc}$ & $454.4 \pm 136.1 \mathrm{~cd}$ \\
\hline & $1.5 \times 3 \mathrm{~m}$ & $9.65 \pm 1.77 \mathrm{ab}$ & $0.96 \pm 0.35 \mathrm{~b}$ & $7.54 \pm 1.92 \mathrm{a}$ & $1.09 \pm 0.93 \mathrm{a}$ & $0.028 \pm 0.016 \mathrm{abc}$ & $466.3 \pm 180.2 \mathrm{~cd}$ \\
\hline & $3 \times 3 \mathrm{~m}$ & $9.10 \pm 2.28 b$ & $0.89 \pm 0.12 \mathrm{~b}$ & $8.96 \pm 2.66 \mathrm{a}$ & $1.88 \pm 1.22 \mathrm{a}$ & $0.043 \pm 0.029 \mathrm{a}$ & $1063.6 \pm 1013.3 \mathrm{~b}$ \\
\hline
\end{tabular}

Note: Numbers followed by different letters in the same column show significant differences based on the results of the Duncan Multiple Range Test (DMRT) at the 5\% level. 


\section{Effects of sengon types and spacing on tree volume}

Measuring tree volume needs to be done to determine what silvicultural treatment should be applied to produce optimal wood productivity. According to Ardelina et al. (2015) farmers may experience losses in the sale of sengon wood if they do not calculate the volume. In Table 3, the interaction between sengon type and spacing resulted in a significant difference in Solomon F2 and local Kendal. The Solomon F2 at $1.5 \times 1.5 \mathrm{~m}$ and $1.5 \times 3 \mathrm{~m}$ spacings were not significantly different, but the $3 \times 3 \mathrm{~m}$ spacing produced significantly lower volume. Meanwhile, the local Kendal at $3 \times 3 \mathrm{~m}$ spacing was not significantly different from $1.5 \times 3 \mathrm{~m}$ spacing, but was significantly higher than $1.5 \times 1.5 \mathrm{~m}$ spacing. This condition was thought that volume growth in Solomon F2 was more responsive to a narrower spacing than local Kendal, which was more responsive to wider spacing.

The sengon tree volume is influenced by stem diameter growth in which fast-growing type could obtain a greater volume than the slow-growing type. In addition to stem diameter, stand density strongly affect tree volume, with a narrower density usually causes narrower growing space, resulting in nutrients and sunlight competition. Craine and Dybzinski (2013) mentioned that every species has different genetic characteristics regarding competition to retrieve nutrients, water, and light. Appropriate species selection and growth location environment are important to support plant capability to adapt to the environment (Venturoli et al. 2014). Villegas et al. (2009) reported that silviculture application treatment through a wider spacing could improve the growth rate of trees while death and damaged trees decrease the number of trees, making a wider growing space for the plant to grow. Suharja and Jumani (2017) and Rahman et al. (2018) mentioned that several factors which influence tree volume in a certain area are species, stand density, growth location quality, and treatments applied.

\section{Effects of sengon types and spacing on canopy area}

Canopy dimension plays an important role in plant growth since the photosynthesis process mainly occurs in this part of the plant (Cavalli and Finger 2016), which eventually affects tree biomass productivity (Goodman et al. 2014). The canopy area is also a good indicator regarding the use and requirement of growth space (Pretzsch et al. 2015). The good growth space availability of a tree can be measured through its canopy width (Sadono et al. 2016). The result showed that the Solomon F2 types had no significant difference among the spacing treatments, while the Solomon F1 at the $3 \times 3 \mathrm{~m}$ spacing was significantly higher in canopy area, followed by local Kendal at the $3 \times 3 \mathrm{~m}$ spacing (Table 3 ).

Increased spacing size is followed by the increased canopy area in Solomon F1 and local Kendal sengon types. The $3 \times 3 \mathrm{~m}$ spacing obtained the best canopy area in Solomon F1 and local Kendal with $2075.3 \mathrm{~m}^{2}$, and 1063.6 respectively (Table 3 ). Narrower spacing as the plant age increases causes the canopy area competition among the plants. A tree with a wider canopy will be more competitive to gain the environmental factors, such as light, nutrients, and water (Sharma et al. 2016). Sadono (2015) explained that the tree canopy shape could change its size and shape due to age variation, growing region, and environmental location.

Planting pattern is closely related to the sengon growth (Dendang and Sudorno 2020). Besides the upland rice plant, there were several studies of food-producing plants cultivated under the sengon stand, such as soybean (Affandi et al. 2019), turmeric (Purnomo et al. 2018), and peanut (Sarminah et al. 2018; Susanto et al. 2021). In this study, the agroforestry of sengon and rice plant impacted sengon growth because the macronutrients initially aimed to fertilize rice plant were indirectly absorbed by the sengon trees. According to Hartoyo et al. (2014), the sengon horizontal roots were found abundantly in agroforestry land compared to monoculture system. Senjaya et al. (2018) also mentioned that roots in agroforestry land could easily obtain more nutrients than roots in monoculture land. Roots play an important role in nutrient and water absorptions which will be distributed to all plant parts, resulting in a good photosynthesis process and other metabolisms (Wijayanto and Hidayanthi 2012). Besides increasing growth, the agroforestry system also becomes a way to suppress pest and disease developments (Rahayu et al. 2021). In the studied area, damaged sengon caused by disease and pest was low, and there were only found damaged branch or tip death caused by weather.

Maintenance activities, such as watering and weeding, could also improve the sengon tree growth quality (Ningrum et al. 2019; Senjaya et al. 2018). The litterfall and rainwater that contains abundant nutrients $(\mathrm{K}$ and $\mathrm{Na}$ ) provide a large amount of $\mathrm{N}, \mathrm{P}, \mathrm{K}, \mathrm{Mg}$, and $\mathrm{Na}$ nutrient concentrations in the soil of agroforestry land as well as the soil organic carbon (Pardon et al. 2017). This condition is similar to the results of soil analysis in the study field that showed an increase in available-P, total-N, and base saturation. According to Rahmawati et al. (2017), initial fertilization in soybean provided nutrients to increase sengon plant growth in agroforestry system compared to monoculture system.

In general, it can be concluded that the three types of sengon at various spacings have optimal growth in agroforestry systems. The growth of Solomon F2 can adapt well to denser spacings $(1.5 \times 1.5 \mathrm{~m}$ and $1.5 \times 3 \mathrm{~m})$ with the highest averages in plant height, stem diameter, volume, and canopy area of $10.50 \mathrm{~m}, 8.65 \mathrm{~cm}, 0.36 \mathrm{~m}^{3}$, and 5.39 $\mathrm{m}^{2}$. Local Kendal has optimal growth at a wider spacing $(3 \times 3 \mathrm{~m})$ with the highest average stem diameter, volume, and canopy area of $8.96 \mathrm{~cm}, 0.043 \mathrm{~m}^{3}$, and $1063.6 \mathrm{~m}^{2}$. While Solomon F1 can adapt well to the three spacings with the highest average in plant height, a growth rate of plant height, stem diameter, volume, and canopy area of $10.05 \mathrm{~m}, 1.54 \mathrm{~m}, 8.59 \mathrm{~cm}, 0.042 \mathrm{~m}^{2}$, and $2075.3 \mathrm{~m}^{2}$. Solomon F1 sengon can adapt well to narrow distances or wide distances. While Solomon F2 is more recommended to be planted at a narrower distance and Kendal local sengon is more recommended to be planted at a wider distance to get optimal growth. Type and spacing selections depend on the agroforestry developmental goal in the future. Wider spacing can provide an opportunity to gain 
optimal rice plant productivity. However, if the development in the future is aimed at wood production, the development will be focused on trees with greater volume and better physical condition.

\section{ACKNOWLEDGEMENTS}

This study is part of basic study topic grant from Prof. Nurheni Wijayanto. Proposal ID: b655f73d-18bb-4233b911-c5ea3d0289fd, entitled Sengon (Paraserianthes falcataria (L.) Nielsen) Agroforestry Development with Upland Rice Plant (Oryza sativa L.) in 2019 funded by Directorate of Research and Public Service, General Directorate of Research and Development, Indonesian Ministry of Research, Technology, and Higher Education.

\section{REFERENCES}

Affandi Z, Purnomo D, Supriyono S. 2019. A study of light intensity and fertilizer on soybean in Albizia chinensis agroforestry system. STJSSA 16 (1): 46-56. DOI: 10.20961/stjssa.v16i1.25872

Agu YPES, Neonbeni EY. 2019. Management models identification of upland dry forest based on traditional agroforestry in Timor island. J Pertan Konservasi Lahan Kering 4 (1): 12-16. DOI 10.32938/sc.v4i01.460 [Indonesian]

Ardelina A, Tiryana T, Muhdin. 2015. Volume model of sengon tree to evaluate the profit loss for community forest's farmer. JPHT 12 (2): 131-139. DOI: 10.20886/jpht.2015.12.2.131-139 [Indonesian]

Azizah N, Wijayanto N, Wirnas D. 2019. The growth and rooting dimensions of the Local and Solomon Albizia in the agroforestry system. Biodiversitas 20 (10): 3018-3023. DOI: 10.13057/biodiv/d201034

[Balitbangtan] Agricultural Research and Development Agency. 2005. Chemical analysis of soil, plants, water and fertilizers. Bogor Soil Research Institute, Agricultural Research and Development Agency, Ministry of Agriculture. Https://balittanah.litbang.pertanian.go.id.

[BMKG] Meteorology, Climatology and Geophysics Agency. 2020 Online data center database for Bogor Climatology Station. Http//dataonline.bmkg.go.id/data_iklim.

Cavalli JP, Finger CAG. 2016. Modelling of upper crown exposed to light of Cedrela fissilis (Vell.) open-grown trees by a non-destructive method. Int J For Res 90 (2): 312-317. DOI: 10.1093/forestry/cpw046

Craine JM, Dybzinski R. 2013. Mechanisms of plant competition for nutrients, water and light. Funct Ecol 27 (4): 833-840. DOI: 10.1111/1365-2435.12081

Darmawan W, Nandika D, Massijaya Y, Kabe A, Rahayu I, Denaud L, Ozarska B. 2015. Lathe check characteristics of fast growing sengon veneers and their effect on LVL glue-bond and bending strength. J Mater Process Technol 215: 181-188. DOI: 10.1016/j.jmatprotec.2014.08.015

Darwiati W, Anggraeni I. 2018. The boktor (Xystrocera festiva Pascoe) and tumor attack (Uromycladium tepperianum (Sacc.) McAlpine) at sengon (Falcataria mollucana (Miq.) in the plantation of Tea Ciater. Sains Natural 8 (2): 59-69. DOI: 10.31938/jsn.v8i2.119. [Indonesian]

Dendang B, Sudomo A. 2020. Growth performance of Falcataria moluccana in the mixed cropping pattern and its severity from Gallrust disease: A case study in Ciamis, West Java. IOP Conf Ser Earth Environ Sci 533 (1): 1-9. DOI: 10.1088/1755-1315/533/1/012044

Dollinger J, Jose S. 2018. Agroforestry for soil health. Agrof Syst 92 (2): 213-219. DOI: 10.1007/s10457-018-0223-9

Goodman RC, Phillips OL, Baker TR. 2014. The importance of crown dimensions to improve tropical tree biomass estimates. Ecol Appl 24 (4): 680-698. DOI: 10.1890/13-0070.1

Hartoyo APP, Wijayanto N, Budi SW. 2014. The physiological response and production of soybeans (Glycine $\max$ (L.) Merrill) tolerant shading based on agroforestry of sengon (Paraserianthes falcataria (L.) Nielsen). JST 5 (2): 84-90. [Indonesian]
Hayati E, Sabaruddin, Rahmawati. 2012. Effect of buds and composition of planting media to the growth of jatropha plants cutting (Jatropha curcas L.) J Agrista 16 (3): 129-134. [Indonesian]

Ikhfan AN, Wijayanto N. 2019. Assessing the growth of local sengon and Solomon sengon in agroforestry system. IOP Conf Ser Earth Environ Sci 394 (1): 1-9. DOI: 10.1088/1755-1315/394/1/012028

Iskandar J, Iskandar BS, Partasasmita R. 2017. Introduction of Paraserianthes falcataria in the traditional agroforestry 'huma' in Karangwangi Village, Cianjur, West Java, Indonesia. Biodiversitas 18 (1): 295-303. DOI: $10.13057 /$ biodiv/d180138

Japarudin Y, Lapammu M, Alwi A, Warburton P, Macdonell D, Boden J, Brawner M, Brown, Meder R. 2020. Growth performance of selected taxa as candidate species for productive tree plantations in Borneo. Aust For 83 (1): 29-38. DOI: 10.1080/00049158.2020.1727181.

Kadigi IL, Mutabazi KD, Philip D, Richardson JW, Bizimana JC, Mbungu W, Mahoo HF, Sieber S. 2020. An economic comparison between alternative rice farming systems in tanzania using a monte carlo simulation approach. Sustainability 12 (16): 1-22. DOI: $10.3390 / \mathrm{su} 12166528$

Khalif U, Utami SR, Zaenal K. 2014. Influence of sengon cultivation (Paraserianthes falcataria) on soil $\mathrm{C}$ and $\mathrm{N}$ content in Slamparejo village, Jabung, Malang. JTSL 1(1):09-15. [Indonesian]

Krisnawati H, Varis E, Kallio M, Kanninen. 2011. Paraserianthes falcataria (L.) Nielsen Ecology, Silviculture and Productivity. Center for International Forestry Research, Bogor.

Lestari P, Rahayu S, Widiyatno. 2013. Dynamics of gall rust disease on sengon (Falcataria moluccana) in various agroforestry patterns. Procedia Environ Sci 17: 167-171. DOI: 10.1016/j.proenv.2013.02.025

Messaoud Y, Chen HY. 2011. The influence of recent climate change on tree height growth differs with species and spatial environment. PLoS One 6 (2): 1-8. DOI: 10.1371/journal.pone.0014691

Ningrum DKB, Wijayanto N, Wulandari AS. 2019. Growth of sengon and production of upland rice and different $\mathrm{p}$ fertilizers in agroforestry system. JST 10 (1): 1-6. DOI: 10.29244/j-siltrop.10.1.1-6 [Indonesia]

Nugroho A, Matra DD, Siregar IZ, Haneda NF, Istikorini Y, Rahmawati R, Amin Y, Siregar UJ. Early growth evaluation and estimation of heritability in a sengon (Falcataria moluccana) progeny testing at Kediri, East Java, Indonesia. Biodiversitas 22 (5): 2728-2736. DOI: $0.13057 /$ biodiv/d220534

Nurliza N, Dolorosa E, Yusra AHA. 2017. Rice farming performance for sustainable agriculture and food security in West Kalimantan. Agraris 3 (2): 84-92. DOI: $10.18196 /$ agr.3248

Nuroniah HS, Tata HL, Mawazin, Martini E, Dewi S. 2021. Assessment on the suitability of planting non-native peatlands species Falcataria moluccana (Miq.) Barneby \& Grimes in rewetted peatlands. Sustainability 13 (13): 1-19. DOI: 10.3390/su13137015

Ozcelik R, Yavuz H, Karatepe Y, Gurlevik N, Kiris R. 2014. Development of ecoregion-based height-diameter models for 3 economically important tree species of southern Turkey. Turk J Agric For 38 (3): 399-412. DOI: 10.3906/tar-1304-115

Pachas ANA, Sakanphet S, Soukkhy O, Lao M, Savathvong S, Newby JC, Souliyasack B, Keoboualapha B, Dieters MJ. 2019. Initial spacing of teak (Tectona grandis) in northern Lao PDR: Impacts on the growth of teak and companion crops. Forest Ecol Manag 435: 77-88. DOI: 10.1016/j.foreco.2018.12.031

Pardon P, Reubens B, Reheul D, Mertens J, De Frenne P, Coussement, Coussement T, Janssens P, Verheyen K. 2017. Trees increase soil organic carbon and nutrient availability in temperate agroforestry systems. Agric Ecosyst Environ 247: 98-111. DOI: 10.1016/j.agee.2017.06.018

Premono BT, Lestari S. 2018. Financial analysis on agroforestry system of coffee with Marrango Tree (Azadirachta excelsa Jack.) in Rejang Lebong Regency, Bengkulu Province, Indonesia. Indones J For Res 5 (1): 45-56. DOI: 10.20886/ijfr.2018.5.1.45-56

Pretzsch H, Biber P, Uhl E, Dahlhausen J, Rötzer T, Caldentey J, Koike T, Con T, Chavanne A, Seifert T, Toit B, Farnden C, Pauleit S. 2015. Crown size and growing space requirement of common tree species in urban centres, parks, and forests. Urban For Urban Green 14 (3): 466 479. DOI: 10.1016/j.ufug.2015.04.006

Purnomo D, Budiastuti MS, Sakya AT, Cholid MI. 2018. The potential of turmeric (Curcuma xanthorrhiza) in agroforestry system based on silk tree (Albizia chinensis). IOP Conf Ser Earth Environ Sci 142 (1): 1-6. DOI: 10.1088/1755-1315/142/1/012034

Rahayu S, Triyoga A, Widyastuti SM, Musyafa', Ardianyah. 2021. Pests and diseases on Falcataria moluccana trees in agroforestry systems 
with pineapple in East Java, Indonesia. Biodiversitas 22 (5): 2779 2788. DOI: $10.13057 /$ biodiv/d220541

Rahman T, Jumani, Emawati H. 2018. Plant stand and stability increment sengon (Albizia falcataria) in Sub Lempake District of North Samarinda. Agrifor 17 (2): 385-394. DOI: 10.31293/af.v17i2.3625. [Indonesia]

Sadono R, Soepridjadi D, Herningtyas W, Rachmadwiati R. 2016. Growing space requirement, diameter, and growth of two generative teak clones in perhutani-the Indonesia state forest enterprise. Adv Environ Biol 10 (4): 273-282.

Sadono R. 2015. Crown shape development of Perhutani's Teak Plus from clonal seed orchards in Madiun, Saradan, and Ngawi Forest District, East Java, Indonesia. Adv Environ Biol 9 (18): 212-221.

Sarminah S, Karyati, Karmini, Simbolon J, Tambunan E. 2018 Rehabilitation and soil conservation of degraded land using sengon (Falcataria moluccana) and peanut (Arachis hypogaea) agroforestry system. Biodiversitas 19 (1): 222-228. DOI: 10.13057/biodiv/d190130

Schwerz F, Neto DD, Caron BO, Nardini C, Sgarbossa J, Eloy E, Behling A, Elli EF, Reichardt K. 2020. Biomass and potential energy yield of perennial woody energy crops under reduced planting spacing. Renew Energy 153: 1238-1250. DOI: 10.1016/j.renene.2020.02.074

Senjaya N, Wijayanto N, Wirnas D, Achmad. 2018. Evaluation of agroforestry system between sengon with upland rice to invection of Rhizoctonia sp. JST 9 (2): 120-126. DOI: 10.29244/j-siltrop.9.2.120126 [Indonesia]

Sepulveda RB, Carrillo AA. 2015. Soil erosion and erosion thresholds in an agroforestry system of coffee (Coffea arabica) and mixed shade trees (Inga spp and Musa spp) in Northern Nicaragua. Agric Ecosyst Environ 210: 25-35. DOI: 10.1016/j.agee.2015.04.032

Setiadi D, Baskorowati L, Susanto M. 2014. Growth of sengon Solomon and its response to gall rusts diseases in Bondowoso, East Java. JPHT 8 (2): 121-136. DOI: 10.20886/jpth.2014.8.2.121-136 [Indonesian]

Sharma LN, Grytnes JA, Maren IE, Vetaas OR. 2016. Do composition and richness of woody plants vary between gaps and closed canopy patches in subtropical forests. JVS 27 (6): 1129-1139. DOI 10.1111 /jvs. 12445

Sollen-Norrlin M, Ghaley BB, Rintoul NLJ. 2020. Agroforestry benefits and challenges for adoption in Europe and beyond. Sustainability 12(17): 7001. DOI: 10.3390/su12177001

Suharja I, Jumani. 2017. Plant increment of ulin (Eusideroxylon zwageri Teijsm \& Binn) in KHDTK Samboja, Samboja sub District, Kutai Kartanegara Regency, Province of East Kalimantan. Agrifor 16 (1): 49-58. [Indonesian]
Susanto A, Winarni M, Parwi. 2021. Peanut productivity under the Albizia stand with agroforestry system in community forest, magetan East Java Indonesia. IJSTM 2 (1): 30-35. DOI: 10.46729/ijstm.v2i1.104

Susanto M, Baskorowati L. 2018. Genetic and environmental effects on sengon growth (Falcataria molucanna) Java Land. Jurnal Bioeksperimen 4 (2): 35-41. DOI: 10.23917/bioeksperimen.v4i2.6883. [Indonesian]

Tun TN, Guo J, Fang S, Tian Y. 2018. Planting spacing affects canopy structure, biomass production and stem roundness in poplar plantations. Scand J For Res 33 (5): 464-474. DOI: 10.1080/02827581.2018.1457711.

Udawatta RP, Rankoth L, Jose S. 2019. Agroforestry and biodiversity. Sustainability 11 (10): 1-22. DOI: $10.3390 / \mathrm{su} 11102879$

Utomo B, Prawoto AA, Bonnet S, Bangviwat A, Gheewala SH. 2016. Environmental performance of cocoa production from monoculture and agroforestry systems in Indonesia. J Clean Prod 134: 583-591. DOI: $10.1016 /$ j.jclepro.2015.08.102

Venturoli F, Franco AC, Fagg CW. 2015. Tree diameter growth following silvicultural treatments in a semi-deciduous secondary forest in Central Brazil. Cerne 21: 117-123. DOI: 10.1590/01047760201521011204

Villegas Z, Peña-Claros M, Mostacedo B, Alarcón A, Licona JC, Leaño, C, Pariona W, Choque U. 2009. Silvicultural treatments enhance growth rates of future crop trees in a tropical dry forest. For Ecol Manag 258 (6): 971-977. DOI: 10.1016/j.foreco.2008.10.031

Wahyudi I, Sinaga DKD, Jasni LB. 2014. Spacing effect on tree growth and several physical-mechanical properties of faster-grown teak wood. JIPI 19 (3): 204-210. [Indonesian]

Wasis B, Saidah SH. 2019. Growth of Paraserianthes falcataria (1.) nielsen seedling on limestone mining site's soil added with compost and npk fertilizer. JST 9 (10): 51-57. DOI: 10.29244/j-siltrop.10.1.5157 [Indonesia]

Widiyanto A, Siarudin M, Rachman E. 2013. Growth of seven provenances of Falcataria mollucana in three spacing. JPAG 1 (2): 1113-121. [Indonesian]

Wijayanto N, Hidayanthi D. 2012. Dimension and rooting system of sentang (Melia excelsa Jack) in agroforestry area. JST 3 (3): 196-202. [Indonesian]

Wijayanto N, Nurunnajah. 2012. Light intensity, temperature, humidity and rooting system of mahogany (Swietenia macrophylla King.) in RPH Babakan Madang, BKPH Bogor, KPH Bogor. JST 3 (1): 8-13. [Indonesian]

Wijayanto N, Pratiwi E. 2011. Shading influence of stand sengon (Paraserianthes falcataria (1.) Nielsen) on growth porang plants (Amorphophallus onchophyllus). JST 2 (1): 46-51. [Indonesian] 